\title{
Nanomaterials in Low-Temperatures Fuel Cells-The Latest Reports
}

\author{
Renata Wlodarczyk \\ Department of Advanced Energy Technologies, Faculty of Infrastructure and Environment, Czestochowa University of \\ Technology, Czestochowa, Poland \\ Email: rwlodarczyk@is.pcz.czest.pl
}

How to cite this paper: Wlodarczyk, R. (2019) Nanomaterials in Low-Temperatures Fuel Cells-The Latest Reports. Materials Sciences and Applications, 10, 643-664. https://doi.org/10.4236/msa.2019.1010046

Received: August 21, 2019

Accepted: October 15, 2019

Published: October 18, 2019

Copyright (c) 2019 by author(s) and Scientific Research Publishing Inc. This work is licensed under the Creative Commons Attribution International License (CC BY 4.0).

http://creativecommons.org/licenses/by/4.0/

\section{(c) (i) Open Access}

\begin{abstract}
Nanotechnology is a field of research with objects up to $100 \mathrm{~nm}$ in size. Nanomaterials belong to a wide area in the field of material engineering. These include nanolayers, nanoslabs, nanopores, nanotubes, nanofibers, nanoparticles and quantum dots. Nanostructures are characterized by special properties due to their nanometric dimensions. The natural properties of nanostructures allow their wide application in various industries. The paper presents an overview of the application and significance of nanostructures in fuel cell technology, with particular emphasis on nanocatalysts. The article includes the classification of nanomaterials, new hybrid nanostructures, types of surface modification, division by area of application, with particular emphasis on nanomaterials in the advanced energy system. The design and operation of fuel cells and the role of nanoparticles have been described taking into account existing solutions to reduce generator costs. The high price of low temperature fuel cells depends on the number of nanoparticles used. The article describes the risk associated with using products at the nano scale. Higher concentrations of these extremely active materials can be dangerous and can cause ecological problems and harm natural ecosystems.
\end{abstract}

\section{Keywords}

Nanocatalyst, Nanoparticles, Low-Temperature Fuel Cell, Hydrogen

Technology

\section{Introduction}

In the light of current problems related to environmental pollution, hydrogen is an attractive energy carrier. This gas has a low ignition initiation energy (thus combustion is more efficient), and its water supply is virtually inexhaustible. 
Problems occur during the storage of hydrogen, because, as a small-molecule gas, it diffuses easily through metals. The most efficient use of hydrogen is possible in fuel cells [1] [2]. In this type of generators, electricity is produced as a result of electrochemical, flameless hydrogen oxidation at the negative electrode and oxygen reduction at the positive electrode. The huge interest in hydrogen fuel cell technology has led to the creation of various types of hydrogen cells taking into account the materials used for electrodes, the type of electrolyte and catalyst, power range, operating temperature, types of reactions occurring on the electrodes, the method of cell utilization.

In low-temperature fuel cells, the speed of processes is supported by nanomaterials (platinum, ruthenium, silver and zirconium nanoparticles). Carbon nanomaterials are also used to build fuel cell components: carbon nanotubes, graphene, fullerenes and others [3] [4]. In the first prototypes of low-temperature fuel cells, the amount of platinum used was about $28 \mathrm{mg} \cdot \mathrm{cm}^{-2}$. In the $1990 \mathrm{~s}$, the amount of catalyst in the electrode structures was reduced to $0.3-0.4 \mathrm{mg} \cdot \mathrm{cm}^{-2}$. Currently, the fragmentation of the catalyst particles ( $4 \mathrm{~nm}$ and less) is deposited on the expanded surface of the carbon powder with a grain diameter of approx. $40 \mathrm{~nm}$ and a specific surface area $>75 \mathrm{~m}^{2} \cdot \mathrm{g}^{-1}$.

This paper presents an overview of possibilities of using nanomaterials in technologies of hydrogen conversion to electric current and heat. The production of hydrogen on a large scale, where nanomaterials are also used as catalysts and energy carriers, is extremely important from the point of view of the distribution of fuel cells. Currently, also hydrogen storage materials are first of all nanomaterials with the shape of $0 \mathrm{D}$ (quantum dots), 1D (wires, tubes, rods), 2D (layers, wells, cylinders), 3D (crystals with nanometer size) [5].

\section{Definition, Characteristics of Nanomaterials and Production Methods}

In a study by the University of Toronto Joint Centre for Bioethics, the first place among the beneficiaries using the properties of nanomaterials is "Energy: production, processing, storage", in front of areas such as agriculture, water treatment, medical diagostics, pharmacy, air protection [6]. According to experts, it is in the field of energy that applying nanotechnology will allow to obtain the greatest potential of helping people and supporting climate protection. Economic development brings with it energy consumption, including renewable energy; properties of nanomaterials give a chance to avoid energy shortages and price fluctuations, and this in turn will help to become independent of fossil fuels. Nanostructured materials are used to build solar cells, hydrogen fuel cells and novel hydrogen storage systems that will provide clean energy to countries still dependent on traditional, non-renewable, polluting fuels.

The definition of nanomaterials introduced by the European Union describes nanomaterial materials with a single particle size in the range of $1-100 \mathrm{~nm}$ [7]. A characteristic feature of nanoparticles is the fact that with the particle size at 
the nano scale, a highly developed surface is obtained, which in turn ensures a high degree of contact between the reagents at the interface. Nanoparticles are ground up to a size smaller than $100 \mathrm{~nm}$, having a different atomic structure and properties than the material they come from [8] [9]. Another definition of nanomaterials formulates them as a material composed of particles in which at least one of the three spatial dimensions is less than $100 \mathrm{~nm}$. Another definition says that a specific product may be called a nanomaterial, when after "miniaturization" to the nanometric dimensions there are changes in its physicochemical properties compared to the product "macro" or solid material [5]. Nanomaterials show many applications in everyday life, in medicine, in the clothing and chemical industry, in agriculture and in the building industry [10] [11]. The special properties of nanomaterials are obtained due to their size at the nano scale. These properties may vary depending on the size and raw material. The main factors causing changes in physicochemical properties of materials are: increased proportion of the number of surface atoms to those inside the particle and the quantum limitation of atoms in small particles of matter. Surface atoms exhibit increased affinity for other atoms, exhibit increased specific volume, altered distribution of electron spins, and intersolar distances [5]. Nanomaterials are characterized, among others, by a high degree of surface development, high chemical reactivity, increased resistance to corrosion, tendency to agglomerate and aggregate. The division of nanomaterials due to the size of particles and their characteristics are given in Table 1. Nano-scale materials can be characterized by a random arrangement of atoms or molecules, i.e. an amorphic structure or ordered structure that can be described in the form of linked polycrystals or monocrystals of appropriate size and orientation [5]. Among the most important factors affecting the quality of manufactured nanostructures is the method of conducting reactions (reduction, chemical, photochemical, electrochemical

Table 1. Dimensional classification of nanomaterials [15].

\begin{tabular}{|c|c|c|}
\hline Particle size & Nanomaterials shape & Graphic characteristics \\
\hline $\begin{array}{l}\text { Dimensional-nanometer size in } \\
\text { all directions }(x, y, z) 0 D\end{array}$ & $\begin{array}{c}\text { quantum dots, clusters, } \\
\text { nanocrystals }\end{array}$ & $\mathrm{D} \leq 100 \mathrm{~nm}$ \\
\hline $\begin{array}{l}\text { one-dimensional nanomaterials, } \\
\text { nano size in two perpendicular } \\
\text { directions }(\mathrm{x}, \mathrm{y}) 1 \mathrm{D}\end{array}$ & $\begin{array}{l}\text { metal nanowires, } \\
\text { nanotubes and nanorods, } \\
\text { nanofibers, nanorods }\end{array}$ & \\
\hline $\begin{array}{l}\text { two-dimensional nanomaterials, } \\
\text { (layers of nano-thickness, } \\
\text { single- or multi-phase types, or } \\
\text { metal composites containing } \\
\text { nanoparticles) 2D }\end{array}$ & $\begin{array}{l}\text { Films and coats, } \\
\text { nanofolies, wells, disc }\end{array}$ & $\mathrm{t} \leq 100 \mathrm{~nm} \uparrow$ \\
\hline $\begin{array}{c}\text { three-dimensional } \\
\text { (nanocrystalline) nanomaterials } \\
\text { 3D }\end{array}$ & $\begin{array}{l}\text { Polycrystals (tetrahedron, } \\
\text { cube, octahedron) }\end{array}$ & $\mathrm{Lx} \neq \mathrm{nm}$ \\
\hline
\end{tabular}


processes) as well as quantitative and qualitative composition of substrates. In addition, the final form of the nanoswap is affected by $\mathrm{pH}$, temperature, and the procedure for conducting the preparation process [12] [13] [14].

Due to their origin, nanomaterials are divided into natural, resulting from the activities of nature: volcanic eruptions, oxidation of minerals, erosion of rocks, sandstorms, atmospheric aerosols or man-made, i.e. antrpogenic origin [5]. Another division of materials on a nano scale divides them into: ceramic and glass-ceramic nanotombs, polymeric, composite nanomaterials (metal-metal, metal-ceramics), and alloys (see Table 2).

Table 3 presents selected areas of nanomaterials in everyday life and in industry. An important problem in the industry causing multimillion losses is corrosion and erosion, that is destruction of equipment in the work environment. This is a problem in the areas of energy (corrosivity of fumes), the aviation industry, refineries, waste incinerators [26] [27]. The use of nanostructured coatings is a solution preventing erosion and corrosion in the industry, increasing the life of components, preventing downtime associated with failure. The most commonly used nanocoating agents are TiAlN, AlCrN, TiNCr, CrN,

Table 2. Selected areas of application of nanomaterials in technical areas.

\begin{tabular}{|c|c|c|c|}
\hline Structure & $\begin{array}{c}\text { Chemical } \\
\text { composition }\end{array}$ & Construction & Ref. \\
\hline Quantum dots & $\begin{array}{l}\text { ZnS, CdS, CdTe, ZnSe, } \\
\text { CdSe InP, GaAS }\end{array}$ & $\begin{array}{l}\text { core made of nanocrystals and } \\
\text { stabilizing ligands }\end{array}$ & $\begin{array}{c}{[15][16]} \\
{[17]}\end{array}$ \\
\hline Nanoparticles & $\begin{array}{c}\mathrm{TiO}_{2}, \mathrm{Fe}_{2} \mathrm{O}_{3}, \mathrm{SiO}_{2} \\
\mathrm{Ag}, \mathrm{Pt}, \mathrm{Au}\end{array}$ & $\begin{array}{l}\text { surfaces modified or used in a dispersed } \\
\text { state }\end{array}$ & {$[18]$} \\
\hline Carbon structures & $\begin{array}{l}\text { Graphene, } \\
\text { nanowire, fullerene, } \\
\text { graphene oxides }\end{array}$ & $\begin{array}{l}\text { surfaces modified with polymers, carbon } \\
\text { nanotubes: SWCNT-Single Wall } \\
\text { Carbon Nanotube (the wall forms one } \\
\text { layer with a diameter of } 1.2-2.0 \mathrm{~nm} \text { ) or } \\
\text { MWCNT-Multiwall Carbon Nanotube } \\
\text { (a diameter of over } 25 \mathrm{~nm} \text { ). }\end{array}$ & $\begin{array}{c}\text { [19] [20] } \\
{[21]}\end{array}$ \\
\hline Films and coats & $\begin{array}{c}\text { Nano films } \\
\text { deposited onto } \\
\text { Au nanoparticles }\end{array}$ & $\begin{array}{l}\text { Nanomaterials developed for localized } \\
\text { surface plasmon resonance (LSPR) are } \\
\text { increasingly integrated into PRR sensors } \\
\text { based on a classical prism, providing } \\
\text { increased sensitivity and lower detection } \\
\text { limits. }\end{array}$ & {$[22]$} \\
\hline $\begin{array}{l}\text { Nano grid, } \\
\text { nano mesh }\end{array}$ & Nanomesh & $\begin{array}{l}\text { 3D nanowires are connected } \\
\text { horizontally on many levels, showing } \\
\text { very regular internal spacing and } \\
\text { dimensions, used to produce more } \\
\text { efficient batteries, better catalysts, fuel } \\
\text { cells and hydrogen production }\end{array}$ & [23] \\
\hline $\begin{array}{c}\text { Dendrymery, } \\
\text { polymeric } \\
\text { nanoparticles (PNPs) }\end{array}$ & & $\begin{array}{l}\text { Nanoparticles suspension in organic } \\
\text { solution/solvent (DMSO, DMF, DMAc, } \\
\text { NMPy)* }\end{array}$ & {$[24][25]$} \\
\hline
\end{tabular}


Table 3. Selected areas of application of nanomaterials in technical areas [26]-[39].

\begin{tabular}{|c|c|c|}
\hline Application & Way to use & Nanomaterials \\
\hline \multirow{5}{*}{ Electronics } & High-density data carriers & \\
\hline & High power magnets & \\
\hline & Quantum dots & \\
\hline & Quantum lasers & \\
\hline & Resistant coatings & $\begin{array}{l}\text { Nanomater-bactericidal properties, } \\
\text { addition to lubricants }\end{array}$ \\
\hline \multirow{3}{*}{ Environment } & Catalyst & - Nanoplatin-electrocatalytic \\
\hline & Water purifiers & properties, \\
\hline & Solar filters & - $\mathrm{TiO}_{2}$ nanoparticles-catalyst, special \\
\hline Industry & $\begin{array}{l}\text { Nanopigments } \\
\text { Membranes and filters } \\
\text { Protective coatings } \\
\text { Antibacterials coatings } \\
\text { Cutting tools }\end{array}$ & $\begin{array}{l}\text { optical and magnetic properties } \\
\text { Silver nanoparticles-bactericidal, } \\
\text { antiseptic properties (fungicidal and } \\
\text { bactericidal) } \\
\text { - Nanozone-a catalyst used in sensors, } \\
\text { biomedicine and pharmacy }\end{array}$ \\
\hline \multirow{5}{*}{ Biomedicine } & Biomarkers & - Nanopallad-catalyst \\
\hline & Controlled release medicine & \\
\hline & Bone implants & \\
\hline & Dentistry & \\
\hline & Contrasts & \\
\hline
\end{tabular}

$\mathrm{Cr}_{3} \mathrm{C}_{2}-\mathrm{NiCr}, \mathrm{Al}_{2} \mathrm{O}_{3}-\mathrm{TiO}_{2}$ [5]. Liquids with dispersed nanoparticles are excellent media that transport heat at maximum speed with low losses. This is due to the fact that nano materials have a higher surface to volume ratio and as an additive suspended in the liquid, improve the thermal conductivity of the fluid. Nanomaterials are used in electronics in systems that provide higher data transfer and storage efficiency than conventional ones. Some of the typical applications are given: [28] [29] [30]. Thanks to the application of these novel components, simple electrical gadgets are gradually replaced by optical or optoelectronic gadgets due to their huge transfer speed. Photonic precious stones are materials with sporadic diversity in the refraction file with a compatible mesh, which is a large part of the wavelength of the light used. Quantum stains are elements at the nanoscale, which can be used, inter alia, for the development of lasers. The preference for a quantum speck laser in relation to a conventional semiconductor laser is that its wavelength depends on the width of the bit. Guided by the help in obtaining food and agriculture in poor countries, nanomaterials are used to accelerate germination and growth of plants [31] [32] [33].

Plants treated with $\mathrm{TiO}_{2}$ nanoparticles had $73 \%$ more dry matter, three times higher photosynthetic rate and a $45 \%$ increase in chlorophyll formation compared to the 30-day control period. The rate of growth of spinach seeds was inversely proportional to the size of the material, which indicates that the smaller the nanomaterials, the better germination. The main reason for the increased rate of growth could be photosterization and photogeneration of "active oxygen, such as superoxide and hydroxide anions" caused by the presence of nanoparticles. Nanomaterials and biocomposites have useful properties that allow them to be used as nanopesticide sensors. High hardness, permeability, crystallinity, 
thermal stability, solubility and biodegradability [34] are essential for building nanopesticides. Nanoemulsions, nanocapsules, nanoconteners and nanocells are some of the recently discussed nanopesticide delivery techniques [35] [36] in the field of plant protection and production.

The unique properties of nanomaterials have been used in biomedical sciences, biotechnology and nanomedicine. Nanomaterials can be useful in in vivo biomedical analysis and in vitro programs. The inclusion of nanotechnology has led to the development of physical rehabilitation methods and drug distribution [37]. Nanotechnology-on-chip diagnostics is yet another dimension of lab-on-a-chip technological innovation. Attractive nanoparticles, limited to the appropriate antibody, are used to label specific elements, components or harmful bacteria. Silver nanoparticles marked with short sections of DNA can be used to recognize inherited series in the example [38]. Scientific tests in medicine are carried out using stains of various sizes embedded in polymeric microspheres. Nanophorous technological innovations also serve to obtain fast information in a digital form about health. Drug intake may be co-administered by the use of an effective broker in the form of dendrimers and mesoporous materials that sends a signal about the drug's effect on health and dosage. This very special strategy reduces the costs and struggles of people. An important aspect of using nanomaterials includes their use in anti-cancer therapies using metal nanoparticles or silver shells [39]. Focused or tailored medicines reduce drug intake and treatment costs, leading to overall social benefits by reducing costs for the public health system. Nanotechnology also opens up new possibilities in the drug distribution techniques using implantable technology.

Nanoscience and nanotechnologies have a large potential to contribute to a sustainable energy system especially for [40] [41] [42] [43] [44]:

- supply and use energy,

- more effective solution production of energy,

- reducing energy consumption achieved thanks to the reduction of power consumption through the use of advanced techniques of insulation materials, the use of more effective lighting techniques (LEDs), huge cage atoms (QCA) or combustion and through the use of lighter and stronger materials in the transport industry [40],

- increasing energy production efficiency by using solar panels to convert energy from the sun into electricity using several different semiconductors placed together, to increase the use of the sun with 40 percent of energy [41], using spray paint enriched with nanoparticles, which after applying in a given place immediately transforms it into a solar panel [42].

- use of more environmentally friendly energy systems through the use of power modules, i.e. fuel cells, in which hydrogen is oxidized, and oxygen from the reduction air, producing electricity [43].

- battery recycling - the use of batteries with a higher energy content or the use of batteries or supercapacitors with a higher regeneration rate using nanomaterials may be useful in terms of battery transfer, will reduce the number 
of used batteries with collectors [44].

Advances in the wide use of nanomaterials for advanced energy systems strongly depend on innovation, efficiency, price and equipment lifetime (see Figure 1). It is expected that the rational design of nanomaterials will play a key role in the development of generators for the production of energy from renewable sources, devices for water purification, exhaust, air, lithium-ion batteries with high energy density, and most importantly for energy storage. The immediate challenge is to reduce the production costs of nanomaterials and their dissemination.

Nanomaterial production methods are divided into top-down methods consisting in a reduction in size with a simultaneous change in the dimensionality of nanoparticle structures, i.e. crushing solid materials to their nano-scale counterparts [45]. These include: crumbling, grinding in ball mills, various types of lithography, laser processing. A material with much better properties, i.e. with fewer defects, a narrow range of grain size and morphology, is obtained using the bottom-up method (the process of building material from the base, i.e. atom to atom) [45] [46] [47]. The growth of monocrystals takes place through the spontaneous joining of individual atoms into larger assemblies (clusters) and aggregation into nanoparticles. The principle of obtaining is based on obtaining nanomaterials by chemical or physical synthesis in the gas phase (CVD) or liquid chemical, direct current glow discharge method, magnetron sputtering, epitaxy from the molecular beam, colloidal methods, electrolytic deposition, hydrolysis reactants. Bottom-up methods include precipitation of nanoproducts in solutions, application of reagents layer by layer (Langmuir-Blodgett technique) [48]. The scheme for obtaining nanoparticles by top-down and bottom-up methods is shown in Figure 2.

The work focuses on the role of nanomaterials in the energy sector, and in particular in hydrogen fuel cells. In fuel cells, nanomaterials are used mainly as

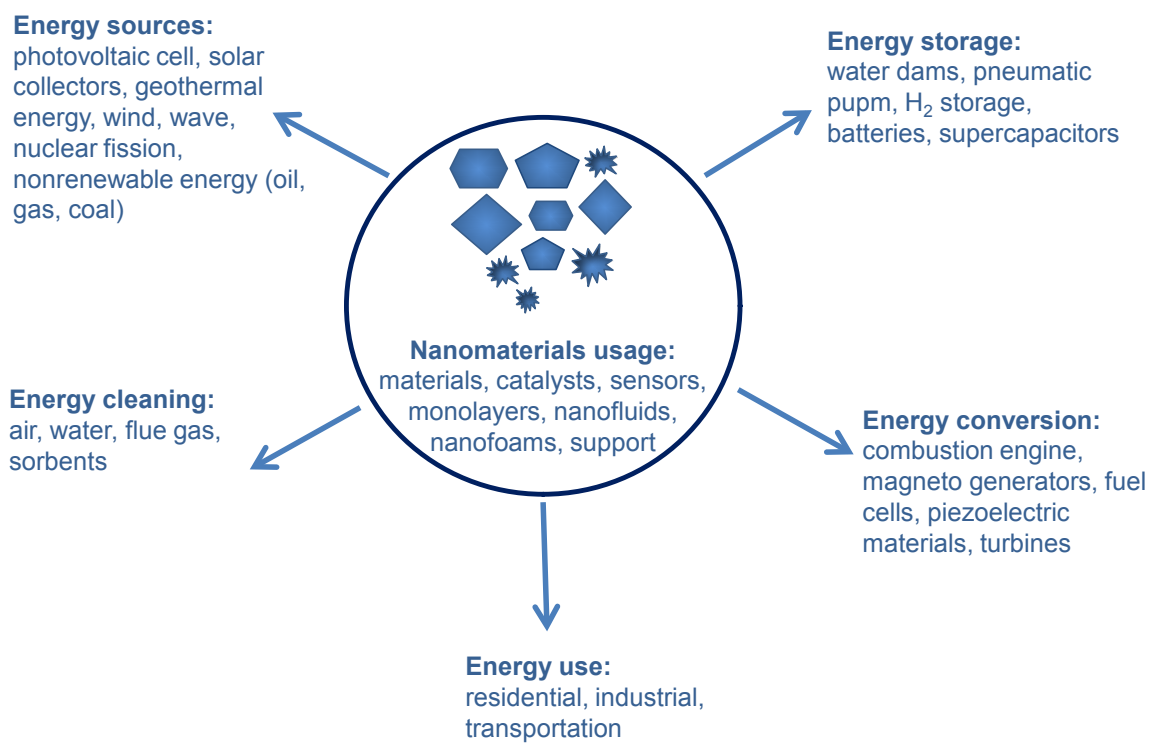

Figure 1. Significant impact of nanomaterials for advanced energy system [40] [41] [42]. 


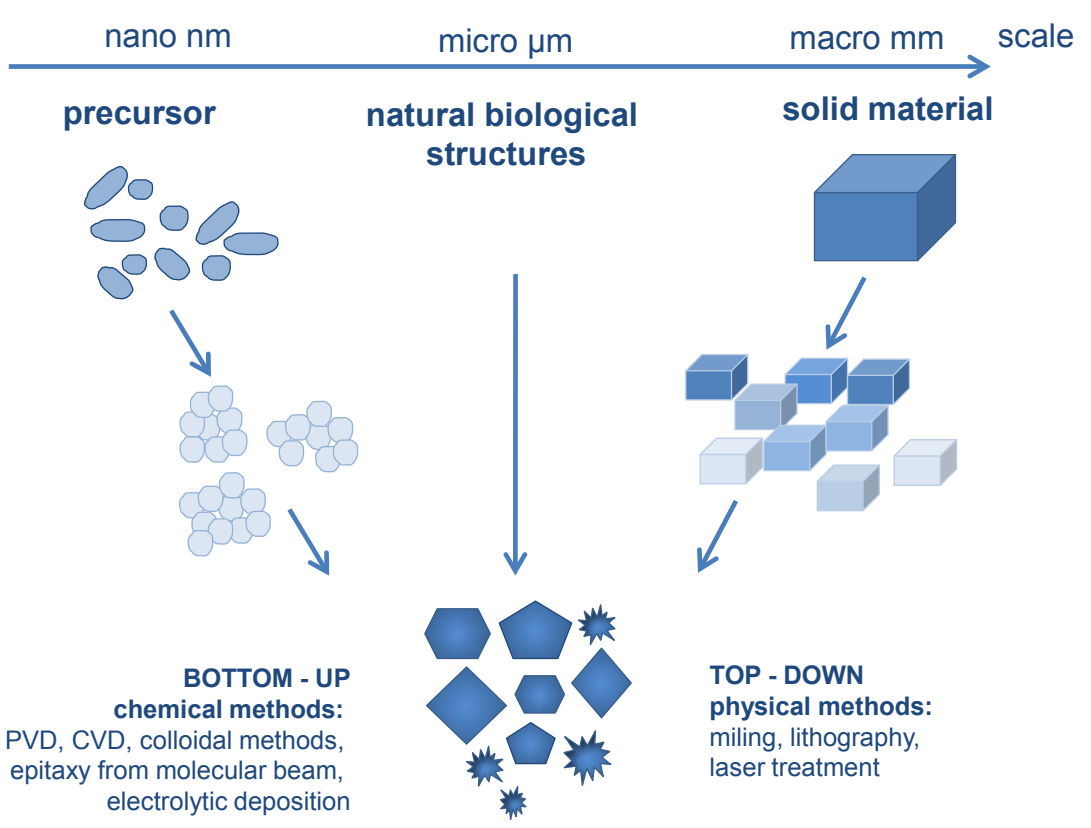

Figure 2. Typical synthetic methods used for nanomaterials for bottom-up and top-down approaches [49] [50] [51].

catalysts for electrochemical processes that occur on electrodes. In hydrogen fuel cells, also carbon-based materials and its allotropic forms are of particular importance, that is: carbon nanotubes, nanocaps, graphene, fullerenes. The mentioned materials, due to their high degree of surface development, are catalyst carriers and basic materials for the construction of fuel cell components.

\section{Construction and Operation of Fuel Cells}

A single cell of a fuel cell consists of an electrolyte/membrane and electrodes, on the surface of which electrochemical reactions and bipolar plates separate the individual cells. Hydrogen and oxygen in the presence of a platinum catalyst undergo oxidation and reduction respectively on the surface of the electrodes. At the cathode, protons (with oxidized $\mathrm{H}_{2}$ ) together with electrons (from $\mathrm{O}_{2}$ reduction) are combined, resulting in water as a by-product. The production of interconnected membrane with electrodes-Membrane Electrode Assembly (MEA), begins by spraying the diffusion layer onto carbon paper, then spraying the catalytic layer with the catalyst and joining both electrodes with the membrane (electrolyte) [47]. The commercially produced electrolyte (usually Nafion) plays an important role in the cell because, thanks to its cation-exchange properties, it transports $\mathrm{H}^{+}$ions, and the electrons resulting from the reaction on the electrodes wander through the external system to the receiver. The cross-section of the electrodes with membrane is shown in Figure 3(a) [51] [52].

Electrochemical processes in low-temperature fuel cells occur on porous electrode surfaces. In the active sites of the electrodes (on the catalysts), gas reactants (oxygen from the air) and protons and electrons meet (Figure 3(b), Figure $3(\mathrm{c})$ ). The electrodes adhere to the electrolyte (Nafion), so the number of active 


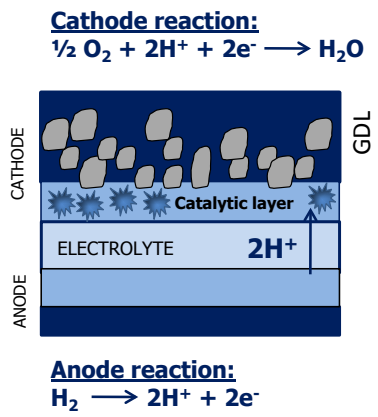

(a)

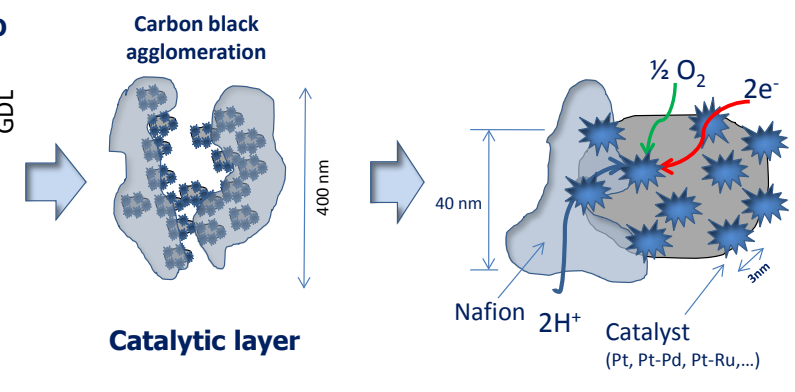

(b)

(c)

Figure 3. Construction of a single cell for a low-temperature PEMFC fuel cell; (a) processes occurring on the catalytic layer of a low temperature cell; (b) a schematic of the structure of the catalytic layer, which is a catalyst deposited on carbon black; (c) a diagram of the processes occurring during the oxygen reduction process at active cathode sites.

sites of the process and the intensity of the process depends on the degree of fragmentation of the catalyst, porosity of the membrane and the degree of joining the ionomer with the catalytic layer.

Hydrogen is not a source of energy but a very effective carrier. Its widespread use seems necessary in the face of growing environmental pollution and electricity deficit. The use of hydrogen potential in generators called fuel cells can replace highly emission technologies. Hydrogen already plays a key role in energy storage and balancing of the power system dominated by renewable energy sources. The use of hydrogen in various branches of the economy is based mainly on fuel cell technology. This technology is similar to the technology of lithium-ion batteries, but fuel cells differ in that they do not need recharging, and uninterrupted supply of fuel allows for continuous operation of the cell. Due to the essence of fuel cell technology, solutions enabling mass production and lowering costs, I will focus on the most expensive elements of the cell, i.e. nanocatalysts (NCs) of electrochemical processes.

\subsection{The Role of Nanomaterials in Fuel Cells}

Hydrogen produced from water, in the process of electrolysis or from renewable energy (from biogas), may in the future become a solution to the energy crisis, which is a real problem in the near future. However, dependence on expensive Pt-based catalysts in such fuel cells remains a major obstacle to the widespread use of this technology. One solution to overcome this situation is to reduce the Pt content tenfold by replacing partial or total catalysts with base metals or alloys with organic compounds. As follows from the considerations below, several breakthroughs have recently occurred that have increased the activity and durability of non-precious metal catalysts, which can now be considered as potential competitors for Pt-based catalysts.

In low-temperature fuel cells, hydrogen and oxygen are introduced into the cell by means of channels in the covers, from where they pass through the por- 
ous diffusion layer to the catalytic layer, where electrochemical processes take place at the active sites of the catalyst. The irreplaceable catalyst for the hydrogen oxidation process is platinum. The oxygen reduction process is catalyzed by platinum or platinum alloys. In the first prototypes of low-temperature fuel cells, the amount of platinum used was about $28 \mathrm{mg} \cdot \mathrm{cm}^{-2}$. In the 1990s, the amount of catalyst in the electrode structures was reduced to $0.3-0.4 \mathrm{mg} \cdot \mathrm{cm}^{-2}$ [53]. The catalyst surface plays an important role here, not the quantity, so the basic principle in the design of the catalytic layer is the high fragmentation of the catalyst particles (4 $\mathrm{nm}$ and less). The catalysts are deposited on the most extensive surface, which is most often a carbon powder with a grain diameter of approx. 40 $\mathrm{nm}$ and a specific surface area $>75 \mathrm{~m}^{2} \cdot \mathrm{g}^{-1}$. The number of active sites should be as large as possible and platinum fineness as high as possible. Platinum is deposited on carbon black, in this mixture the $\mathrm{Pt} / \mathrm{C}$ ratio should be about $40 \%$ by mass. High platinum content allows to obtain higher cell voltage but this way of proceeding increases the production costs of the cell.

The oxygen reduction process (ORR-Oxygen Reduction Reaction) in fuel cells takes place on a positive electrode, called a cathode. The binding in the oxygen molecule is very strong and therefore difficult to tear. To do this, use four electrons per oxygen molecule, which gives one molecule of water, and the more atoms and electrons that are involved in the electrochemical process, the more difficult and slow the reaction. Each half reaction is in fact a series of intermediate reactions or steps that make up the reaction mechanism. Of the many possible reaction steps or the mechanism of a given half reaction, only individual electron transfer reactions are possible. The total process speed depends on the slowest process and this process determines the ORR reaction rate. As is clear from the considerations, the ORR processes are complicated and long-lasting, requiring the use of catalysts, so that processes can occur at a suitable rate at ambient temperature and at a given pressure. The most desirable way to reduce oxygen is when it goes with four electrons to water. ORR can take two paths. The first, commonly referred to as partial reduction, involves a process with the formation of two electrons resulting in the production of adsorbed hydrogen peroxide. The full reduction follows the more efficient pathway of the four electrons, which does not involve the production of $\mathrm{H}_{2} \mathrm{O}_{2}$ [54] [55] [56]. Due to the improved full reduction efficiency as well as the relatively high reactivity of hydrogen peroxide compared to water stability, full reduction is the path sought when choosing a catalyst for ORR.

For partial reduction, oxygen is first adsorbed on the surface of the catalyst. Thereafter, the reaction with the protons from hydrogen oxidation takes place, resulting in the formation of $\mathrm{H}_{2} \mathrm{O}_{2}$, the molecule of which is adsorbed on the catalyst. The reaction product in the form of hydrogen peroxide may then be further reduced to produce two molecules of water, or it may simply dissociate, giving a free molecule of $\mathrm{H}_{2} \mathrm{O}_{2}$ [56].

Electrodes produced using platinum catalyst nanoparticles seem to be displaced in recent times. The main reason lies in the high cost of cell production. 
Among other things, Pt-Cr, Pt-Pd, Pt-Fe, Pt-Co, Pt-Ru, Pt-Sn, Pt-Ni, Pt-WO3 [57] [58] [59] and platinum with heteropoly compounds [60] [61] were investigated. These substances are very good proton relays, and have the ability of spontaneous adsorption on the surface of a solid (eg glassy carbon or platinum). The most promising compounds of this group are polyoxometalates: $\mathrm{H}_{3} \mathrm{SiW}_{12} \mathrm{O}_{40}$, $\mathrm{H}_{3} \mathrm{SiMo}_{12} \mathrm{O}_{40}, \mathrm{H}_{3} \mathrm{PW}_{12} \mathrm{O}_{40}, \mathrm{H}_{3} \mathrm{PMo}_{12} \mathrm{O}_{40}$. The heteropoly compound group shows a relationship between size and physicochemical properties, these compounds have optical properties (right and left torsion structures), aqueous solutions of HTPA are strong completely dissociated acids. The undoubted advantage of polyoxometalates is the simplicity of making a multilayer and, at the same time, thin film, a layer-by-layer method, and consists in applying successive layers to the carbon paper substrate [58] [59]. The catalytic properties of the metal are affected by the crystallographic structure of the catalyst. Recent studies have shown that, depending on the type of crystallographic platinum: Pt (111), Pt (100) or Pt (110) ORR kinetics follow different mechanisms [64] [65]. The authors of the work showed that $\mathrm{Pt}(111)$ has the most weakest catalytic properties. Platinum, palladium and platinum-metal alloys have excellent catalytic properties on the negative electrode (anode). According to the literature data, depending on the electrode's shape, these metals are used in an amount of 1 - 20 $\mathrm{mg} \cdot \mathrm{cm}^{-2}$ [66], and more recently even $0.2 \mathrm{mg} \cdot \mathrm{cm}^{-2}$ [67], with particles having to be ground at how much is possible.

The classification of nanocatalysts (NC), which accelerate the ORR process in fuel cells, is presented in Table 4. It is divided into three groups: precious metals, base metal electrodes and organometallic compounds. Platinum is the most commonly used nanocatalyst for oxygen reduction in an acidic environment. With the reduction in the size of platinum particles, the development of the surface increases considerably, which improves the use of the catalyst. A change in the diameter of the nanoparticle from $12 \mathrm{~nm}$ to $2 \mathrm{~nm}$ increases the development of the platinum surface from $25 \mathrm{~m}^{2} \cdot \mathrm{g}^{-1}$ to $150 \mathrm{~m}^{2} \cdot \mathrm{g}^{-1}$ [68] [69].

\section{2. "Poisoning" of the Catalyst on the Surface of the Anode}

The phenomenon of poisoning of electrodes concerns first of all those fuel cells to which the fuel fed requires initial preparation (e,g. DMFC and others). Reforming is a steam process of transforming methane (and other light hydrocarbons) into hydrogen and carbon monoxide. At temperatures between $700^{\circ} \mathrm{C}$ $1100^{\circ} \mathrm{C}$, water vapor reacts with methane to form three hydrogen molecules and carbon monoxide. The whole process takes place in the presence of a metal catalyst. Reforming is usually done in the so-called reformers, or devices installed in front

Table 4. Materials commonly used as catalysts of ORR in fuel cells.

\begin{tabular}{ccc}
\hline Nanoparticles & Solid materials & Organo-metallic composites \\
\hline $\mathrm{TiO}_{2}$ deposited onto $\mathrm{Au}$ & $\mathrm{Pt}, \mathrm{Ru}, \mathrm{Cu}-\mathrm{Ru}, \mathrm{Au}, \mathrm{Pd}-\mathrm{Co}$ & transition metal complexes with \\
$\mathrm{Pd}$ deposited onto $\mathrm{Au}$ & $\mathrm{Cu}, \mathrm{Ni}, \mathrm{TiO} 2, \mathrm{Ti}, \mathrm{V}_{2} \mathrm{O}_{5}$ & $\begin{array}{c}\text { porphyrin ligands } \\
\text { - metal complexes }\end{array}$ \\
\hline
\end{tabular}


of cell cells. The hydrogen is already fed to the cell, containing some admixtures of $\mathrm{CO}$ and $\mathrm{CO}_{2}$. It has been proven that the efficiency of cell energy conversion is already falling at several ppm of carbon monoxide present in the cell. This is due to high $\mathrm{CO}$ chemisorption to platinum. $\mathrm{CO}$ is deposited on the Pt nanoparticle, thereby reducing the area of the active metal surface [70]. There are two methods to reduce the scale of catalyst poisoning on the electrode [71] [72]. The first is the interference in the reforming process, the second is the use of Pt-based alloys. The task of alloys is to bind $\mathrm{CO}$ before it is bound by pure platinum. The first method can include: selective oxidation, catalytic reforming. Selective oxidation is the most commonly used method. It consists in subjecting additional reforming products to the oxidation (whether using oxygen or air). As a result of the process, the amount of $\mathrm{CO}_{2}$ increases at the expense of $\mathrm{CO}$ decline. In addition, to improve the selective oxidation process, an additional catalyst is used, which is placed just before the cell anode. The use of the selective oxidation method may contribute to reducing the amount of $\mathrm{CO}$ in the fuel even up to $<10 \mathrm{ppm}$ [69]. The CO content in the reforming products can be significantly reduced by using a platinum (or aluminum) catalyst to "capture" the $\mathrm{CO}$ particles in front of the cells cell. This method allows to reduce the concentration of carbon monoxide in fuel to $100 \mathrm{ppm}$. Alloys that bind adsorbed CO, poisoning catalyst (reducing the surface of the active catalyst) are listed in Table 5. A list of selected binary and ternary alloys based on platinum with additions of the following metals is provided here: ruthenium $(\mathrm{Ru})$, tin $(\mathrm{Sn})$, molybdenum (Mo), tungsten oxide (WO), iridium (Ir), rhodium (Rh), osmium (Os), rhenium (Re).

Currently, catalysts based on Pt nanoparticles are still the most active materials, low temperature hydrogen fuel cells, reformate or methanol [82]. Pt alloying with transition metals increases the electrocatalisation of $\mathrm{O}_{2}$ reduction. In low-temperature fuel cells it was observed that $\mathrm{Pt}-\mathrm{Fe}, \mathrm{Pt}-\mathrm{Cr}$ and $\mathrm{Pt}-\mathrm{Cr}$-Co electrocatalysts have high specific activity for oxygen reduction compared to

Table 5. Types of alloys counteracting poisoning of catalysts.

\begin{tabular}{|c|c|c|c|c|}
\hline $\begin{array}{l}\text { Nanocatalyst types } \\
\text { (NC) }\end{array}$ & Way to use & Nanomaterials shape & Properties & Ref. \\
\hline $\mathrm{Pt}$ & $\mathrm{Pt} / \mathrm{C}$ & nanoparticles & High prices and high stability & [62] [63] [64] [65] \\
\hline $\begin{array}{l}\text { Bi-component alloys } \\
\text { based onto Pt }\end{array}$ & $\begin{array}{c}\mathrm{Pt}-\mathrm{Co} / \mathrm{C}, \mathrm{Pt}-\mathrm{Cr} / \mathrm{C}, \mathrm{Pt}-\mathrm{Fe} / \mathrm{C}, \\
\mathrm{Pt}-\mathrm{Ir} / \mathrm{C}, \mathrm{Pt}-\mathrm{Mn} / \mathrm{C}, \mathrm{Pt}-\mathrm{Mo} / \mathrm{C} \\
\mathrm{Pt}-\mathrm{Ni} / \mathrm{C}, \mathrm{Pt}-\mathrm{Pd} / \mathrm{C}, \mathrm{Pt}-\mathrm{Rh} / \mathrm{C} \\
\mathrm{Pt}-\mathrm{Ru} / \mathrm{C}, \mathrm{Pt}-\mathrm{W} / \mathrm{C}\end{array}$ & $\begin{array}{c}\text { Nanoparticles } \\
(\mathrm{d}=4.5-8.5 \mathrm{~nm}), \text { nanofoams, } \\
\text { nanodendryts nanotetrahedrs, } \\
\text { nanocrystals, nanofilms, } \\
\text { frusto-octahedron nanoparticles }\end{array}$ & Low price, relatively low stability & $\begin{array}{c}{[73][74][75][76]} \\
{[77]}\end{array}$ \\
\hline $\begin{array}{l}\text { Three-component } \\
\text { alloys based onto Pt }\end{array}$ & $\begin{array}{c}\mathrm{Pt}-\mathrm{Ru} / \mathrm{Al}_{4}, \mathrm{Pt}-\mathrm{Ru}-\mathrm{Cr} / \mathrm{C} \\
\mathrm{Pt}-\mathrm{Ru}-\mathrm{Mn} / \mathrm{C}, \mathrm{Pt}-\mathrm{Ru}-\mathrm{Co}, \\
\mathrm{Pt}-\mathrm{Ru}-\mathrm{Nb} / \mathrm{C}, \mathrm{Pt}-\mathrm{Ru}-\mathrm{Ni} / \mathrm{C} \\
\mathrm{Pt}-\mathrm{Ru}-\mathrm{Pd} / \mathrm{C}, \mathrm{Pt}-\mathrm{Ru}-\mathrm{Rh} / \mathrm{C} \\
\mathrm{Pt}-\mathrm{Ru}-\mathrm{W} / \mathrm{C}, \mathrm{Pt}-\mathrm{Ru}-\mathrm{Zr} / \mathrm{C} \\
\quad \mathrm{Pt}-\mathrm{Re}-\left(\mathrm{MgH}_{2}\right)\end{array}$ & $\begin{array}{c}\text { Nanoparticles, nanofilms, } \\
\text { nanowires }\end{array}$ & $\begin{array}{l}\text { Low price, high durability under } \\
\text { special conditions }\end{array}$ & [78] [79] [80] \\
\hline Alloys non Pt-catalyst & $\mathrm{Au}-\mathrm{Pd} / \mathrm{C}$ & Nanoparticles & $\begin{array}{c}\text { Low price, un-exhausted resources, } \\
\text { relatively low activity }\end{array}$ & {$[81]$} \\
\hline
\end{tabular}


Pt-electrocatalysts [83] [84]. This increase in electrocatalytic activity has been attributed to several factors, such as interatomic spacing, preferred orientation or electronic interactions. The state-of-the-art Pt-Co-Cr electrocatalysts have a particle size of $6 \mathrm{~nm}$ [85]. Pt alloys with Mn, Co, Fe and Ni exhibit higher catalytic activity than their spherical counterparts in the field of oxygen reduction, oxidation of formic acid and methanol oxidation. Zhang et al. [86] developed a method for the synthesis of a solution in a single vessel in order to produce a platinum-iridium catalyst with nanodendrometric morphology and a homogeneous dispersion of particles with a diameter of $15 \mathrm{~nm}$. The nanodendritic nature of the particles caused an increase in the electrochemical surface. The platinum synthesis from $\mathrm{Au}$ allowed to obtain a monodisperse $\mathrm{Pt} / \mathrm{Au}$ nanodendron $(\sim 15 \mathrm{~nm})$. The produced IrRe nanoparticles (NP) were then coated with a $\mathrm{Pt}$ monolayer or Pt monolayer on a single Pd layer by means of galvanic deposition, which resulted in Pt/IrRe and Pt/Pd/IrRe catalysts with diameters of $\sim 4 \mathrm{~nm}$ [87], respectively. Shao in al. [88] experimented with depositing the platinum monolayer on gold nanoparticles. The resulting catalysts were monodispersed $(\sim 3 \mathrm{~nm})$ particles. The particle size of $\mathrm{Pt} / \mathrm{C}$ catalysts was $\sim 2.8 \mathrm{~nm}$, almost identical to the $\mathrm{Pt} / \mathrm{Au}$ NP. The catalyst consisting of the IrNi core was first covered with an iridium monolayer and then with a platinum monolayer. The catalysts obtained had a diameter of $\sim 5 \mathrm{~nm}(\mathrm{Pt} / \mathrm{Ir} / \mathrm{IrNi})$ [89]. Table 6 presents selected compositions based on nanomaterials of various crystallographic structures, whose chemical

Table 6. Review of Pt-based catalysts doped with precious metals [87] [88] [89] [90] [91].

\begin{tabular}{|c|c|c|}
\hline Catalyst & Electrolyte/Methods & Properties \\
\hline $\begin{array}{l}\text { Nano dendrites } \\
\text { Pt/Ir }\end{array}$ & $\begin{array}{l}0.5 \mathrm{~mol} \cdot \mathrm{dm}^{-3} \mathrm{H}_{2} \mathrm{SO}_{4} \\
\text { sat. with } \mathrm{O}_{2}\end{array}$ & $\begin{array}{l}\text { The reasons for the increase in ORR activity compared } \\
\text { to Black Pt/Ir were considered: the nanodendric nature } \\
\text { of the particles, which led to an increase in the } \\
\text { electrochemical surface; and interactions of iridium } \\
\text { core with platinum coating. }\end{array}$ \\
\hline $\begin{array}{l}\text { Nano dendrites } \\
\text { Pt/Au }\end{array}$ & $\begin{array}{l}0.1 \mathrm{~mol} \cdot \mathrm{dm}^{-3} \mathrm{HClO}_{4} \\
\text { sat. with } \mathrm{O}_{2}\end{array}$ & $\begin{array}{l}\text { Better ORR activity was observed, which probably } \\
\text { results from a large electrochemical surface created in } \\
\text { nano dendric buildings. }\end{array}$ \\
\hline $\begin{array}{l}\text { Nano dendrites } \\
\text { Pt/IrRe }\end{array}$ & $\begin{array}{l}0.1 \mathrm{~mol} \cdot \mathrm{dm}^{-3} \mathrm{HClO}_{4} \\
\text { sat. with } \mathrm{O}_{2}\end{array}$ & $\begin{array}{l}\text { With the change in the composition of IrRe, the } \\
\text { binding energy of the -OH catalyst changes, the ORR } \\
\text { activity also changes. }\end{array}$ \\
\hline $\begin{array}{l}\text { Pt monolayers }(\mathrm{ML}) \\
\text { on the } \mathrm{Au} \\
\text { nanoparticles }(\mathrm{NP})\end{array}$ & $\begin{array}{l}0.1 \mathrm{~mol} \cdot \mathrm{dm}^{-3} \mathrm{HClO}_{4} \\
\text { sat. with } \mathrm{O}_{2}\end{array}$ & $\begin{array}{l}\text { No drastic changes in particle size in PtC and ML } \\
\text { Pt/NP Au catalysts }\end{array}$ \\
\hline $\begin{array}{l}\text { Nanospheres } \\
\text { Pt/Ir-Ni }\end{array}$ & $\begin{array}{l}0.1 \mathrm{~mol} \cdot \mathrm{dm}^{-3} \mathrm{HClO}_{4} \\
\text { sat. with } \mathrm{O}_{2}\end{array}$ & $\begin{array}{l}\text { Pt coatings with pure Ir core caused too strong binding } \\
\text { of -OH molecules. Ni particles added to the core } \\
\text { weaken the catalyst binding -OH to } \mathrm{Pt} / \mathrm{Ir} \text {, and } \\
\text { strengthen binding to } \mathrm{Pt} \text {. Higher activity of } \mathrm{Pt} / \mathrm{IrNi} \\
\text { catalysts compared to } \mathrm{Pt} / \mathrm{C} \text { gives higher ORR activity. }\end{array}$ \\
\hline Nanowire $\mathrm{Pt} / \mathrm{Pd}$ & $\begin{array}{l}0.1 \mathrm{~mol} \cdot \mathrm{dm}^{-3} \mathrm{HClO}_{4} \\
\text { sat. with } \mathrm{O}_{2}\end{array}$ & $\begin{array}{l}\text { High activity of the } \mathrm{Pt} / \mathrm{Pd} \text { catalyst results from the } \\
\text { relationship between metals, this does not refer to the } \\
\text { degree of development of the active surface }\end{array}$ \\
\hline
\end{tabular}


activity for the ORR process has been studied in acidic saturated oxygen environments. Platinum based alloys did not lose their catalytic properties.

Platinum catalysts doped with precious metals or transition metals are the most effective alloys in terms of ORR activity. High hopes are related to the future use of platinum-free catalysts, which are cheaper and exhibit catalytic properties of reduction processes. Research on the use of ORR catalysts has allowed to classify them into generations:

- 1 st generation-increasing the activity of pure Pt catalysts,

- 2nd generation-involved in the preparation of Pt alloys which simultaneously increased ORR activity while decreasing platinum content,

- 3rd generation-developed precious metal catalysts,

- 4th generation-search for ORR catalysts does not apply to metals.

\section{Threats and Prospects of Nanomaterials in Fuel Cells Development}

Nanotechnology and nanomaterials seem to be a field of science with unlimited use. Although it is a relatively new field of science, it is now observing and predicting dangers and consequences [91]. Some properties of nanomaterials recognized universally as unique, such as small size, large specific surface area or surface activity, may cause their toxicity to the environment and living organisms. Important factors determining the toxicity of these substances is also the size distribution of nanoparticles, shape, chemical composition, electron properties, reactivity of surface groups and the ability to aggregate. It should be remembered that nanomaterials are often characterized by different properties compared to their counterparts in the "macroscopic" scale. Often, normally inert materials for living organisms show a significant increase in toxicity when the size of the particles forming them decreases to the nanometric scale. This toxicity may be caused by an easier, increased release of heavy metal ions from the surface of nanoparticles, caused by porosity of nanoparticles, tendency to agglomerate, significant chemical affinity for many biological structures or increased chemical reactivity of their surface.

With such a pace of development of nanotechnology, special attention should be paid to the methods of utilizing nano-scale materials [92] [93]. These materials undergo many transformations in the natural environment, such as aggregation, dissolution and oxidation. Higher concentrations of these extremely active materials can be dangerous and can cause ecological problems and harm natural ecosystems. Understanding all phenomena related to the presence of nanoparticles that have somehow gone into the soil or into the ecosystem and the relationship and transformation of nanoparticles will help formulate remedial actions in the face of increasing their nanomaterials from the utilization of industrial components. The most important barrier in nanomaterial risk management is the technology developed to detect these materials, including portable devices for faster diagnosis and measurement. On the safety of nanomaterials on the environment. Still as lack of information about the tests that are currently 
available, they are available on the amount of nanoparticles. Meanwhile, the toxicity of these materials. It is necessary to provide the society with society, while ensuring security.

In the future, it is planned to use fuel cells for biomedical applications, inter alia as biocells and as micro devices intended for the production of electricity. In the near future, the most promising market for nanomaterials in the energy sector will probably be the development of hydrogen technologies, including fuel cells.

\section{Conclusions}

Despite many world successes in the field of fuel cell technology, work on improving cells continues. At the moment, work is being done intensively on solving the issue of hydrogen generation and storage, reduction of generator production costs and their miniaturization. An obstacle in the commercialization of these solutions is the high cost of materials, high weight of instrumentation and hydrogen storage (no hydrogen infrastructure). Since the early 1950's, significant advances have been made towards lowering the price of the cell and increasing power. However, fuel cells are still too expensive and their service life (about 10,000 hours) is too short. The operation of fuel cells depends to a large extent on the purity of the fuel and the condition of the catalyst. Contaminants cause catalyst "poisoning". At high costs of the catalyst, which is platinum, taking care of its stability and durability during the work of the cell is extremely important. Also the water management in the cell must be optimized: too high a level of moisture can cause the membrane to "flood"; too low a level will cause the diaphragm to dry out and its irreversible destruction. The extremely important role of catalysts, in the form of nanomaterials, requires continuous research on the materials from which cell elements are built. There are two ways to obtain perfect materials: modification of already known materials or reaching for new materials and use of nanotechnology. As can be seen from the above considerations, the transition from bulk materials to nanoscale can significantly change the electrode and durability of fuel cells. Nanoparticles have catalytic capabilities of the processes taking place in the cell, but also nanostructures with other morphologies (nanotubes, nanowires, nanofoams, nanospheres, nanodendrites, nanorods, nanooctahedra) are also effective. On the other hand, nanomaterials also have disadvantages, such as low thermodynamic stability, high surface reaction, and possible toxicity problems. The solution of challenges related to the design of optimized hybrid nanostructures and surface modification, the implementation of systematic testing of nanomaterials properties and control of their operation on the environment, determination of procedures related to the detection of nanostructures, will be a major breakthrough in the development of nanoscience in hydrogen technology.

\section{Funding}

This research was funded by grants BSPB-400-301/19. 


\section{Conflicts of Interest}

The author declares no conflict of interest.

\section{References}

[1] Alves, H.J., Junior, C.B., Niklevucz, R.R., Frigo, E.P., Frigo, M.S., Coimbra-Araujo C.H., (2013) Review Overview of Hydrogen Production Technologies from Biogas and the Applications in Fuel Cells. International Journal of Hydrogen Energy, 38, 5215-5225. https://doi.org/10.1016/j.ijhydene.2013.02.057

[2] Manoharan, Y., Hosseini, S.H., Butler, B., Alzhahrani, H., Fou Senior, B.T. and Krohn, J. (2019) Hydrogen Fuel Cells Vehicles: Current Status and Future Prospects. Applied Sciences, 9, 2296-2313. https://doi.org/10.3390/app9112296

[3] Ball, M. and Wietschel, M. (2009) The Future of Hydrogen-Opportunities and Challenges. International Journal of Hydrogen Energy, 34, 615-627. https://doi.org/10.1016/j.ijhydene.2008.11.014

[4] Mehta, V. and Cooper, J.S. (2003) Review and Analysis of PEM Design and Manufacturing. Journal of Power Sources, 114, 32-53. https://doi.org/10.1016/S0378-7753(02)00542-6

[5] Antolini, E., (2004) Recent Developments in Polymer Electrolyte Cell Electrodes. Journal of Applied Electrochemistry, 156, 563-576. https://doi.org/10.1023/B:JACH.0000021923.67264.bb

[6] University of Toronto Joint Center for Bioethics (2005) Nanotechnology in Construction-One of the Top Ten Answers to World's Biggest Problems. https://www.aggregateresearch.com

[7] The European Commission (2011) Commission Recommendation of 18 October 2011 on the Definition of Nanomaterial. Official Journal of the European Union, No. 275/38, 38-40.

[8] Li, Y., Zhang, W., Niu, J. and Chen, Y. (2013) Surface-Coating-Dependent Dissolution, Aggregation, and Reactive Oxygen Species (ROS) Generation of Silver Nanoparticles under Different Irradiation Conditions. Environmental Science \& Technology, 47, 10293-10301. https://doi.org/10.1021/es400945v

[9] Mathew, J., Joy, J. and George, S.C. (2018) Potential Applications of Nanotechnology in Transportation: A Review. Journal of King Saud University-Science, In Press. https://doi.org/10.1016/j.jksus.2018.03.015

[10] Sharma, V.P., Sharma, U., Chattopadhyay, M. and Shukla, V.N. (2018) Advance Applications of Nanomaterials: A Review. Materials Today: Proceedings, 5, 63766380. https://doi.org/10.1016/j.matpr.2017.12.248

[11] Khan, I., Saeed, K. and Khan, I. (2017) Nanoparticles: Properties, Applications and Toxicities. Arabian Journal of Chemistry, In Press. https://doi.org/10.1016/j.arabjc.2017.05.011

[12] Rajput, N. (2015) Methods of Preparation of Nanoperticles-A Review. International Journal of Advanced Engineering Technology, 7, 1806-1811.

[13] Hasany, S.F., Ahmad, I., Ranjan, J. and Rehman, A. (2012) Systematic Review of the Preparation Techniques of Iron Oxide Magnetic Nanoparticles. Nanoscience \& Nanotechnology, 2, 148-158. https://doi.org/10.5923/j.nn.20120206.01

[14] Chang, W., Skandan, G., Hahn, H., Danforth, S.C. and Kear, B.H. (1994) Chemical Vapour Condensation of Nanostructured Ceramic Powders. Nanostructured Materials, 4, 345-351. https://doi.org/10.1016/0965-9773(94)90144-9

[15] Stone, V., Nowack, B., Baun, A., van den Brick, N., von der Kramer, F., Dusinska, 
M., Handy, R., Hankin, S., Hasselov, M., Joner, E. and Fernandes, T.F. (2010) Nanomaterials for Environmental Studies: Classification, Reference Material Issues, and Strategies for Physico-Chemical Characterization. Science of the Total Environment, 408, 1745-1754. https://doi.org/10.1016/j.scitotenv.2009.10.035

[16] Fadeel, B. and Garcia-Bennett, A.E. (2010) Better Safe than Sorry: Understanding the Toxicological Properties of Inorganic Nanoparticles Manufactured for Biomedical Application. Advanced Drug Delivery Reviews, 62, 362-374.

https://doi.org/10.1016/j.addr.2009.11.008

[17] Moritz, M. (2012) Zastosowanie nanomateriałów w naukach medycznych. Chemik, 66, 219-226.

[18] Zhang, Y., Zhi. Z., Jing, T., Zhang, J., Wang, Z. and Wang, S. (2010) Spherical Mesoporous Silica Nanoparticles for Loading and Release of the Poorly Water-Soluble Drug Telmisartan. Journal of Controlled Release, 145, 257-263. https://doi.org/10.1016/j.jconrel.2010.04.029

[19] Bachmatiuk, A., Borowiak-Palen, E. and Kalenczuk, R.J. (2008) Advances in Engineering of Diameter and Number of Walls Distributions of Carbon Nanotubes in Alcohol-CVD. Nanotechnology, 19, 365605-365612. https://doi.org/10.1088/0957-4484/19/36/365605

[20] Gan, T. and Hu, S. (2011) Electrochemical Sensors Based on Graphene Materials. Microchimica Acta, 175, 1-19. https://doi.org/10.1007/s00604-011-0639-7

[21] Inagaki, M., Kaneko, K. and Nishizawa, T. (2004) Nanocarbons-Recent Research in Japan. Carbon, 42, 1401-1417. https://doi.org/10.1016/j.carbon.2004.02.032

[22] Bolduc, O.R. and Masson, J.-F. (2011) Advances in Surface Plasmon Resonance Sensing with Nanoparticles and Thin Films: Nanomaterials, Surface Chemistry, and Hybrid Plasmonic Techniques. Analytical Chemistry, 83, 8057-8062. https://doi.org/10.1021/ac2012976

[23] https://www.eenewspower.com

[24] Cruho, C.I.C. and Barros, M.T. (2017) Polymeric Nanoparticles: A Study on the Preparation Variables and Characterization Methods. Materials Science and Engineering $C$, 80, 771-784. https://doi.org/10.1016/j.msec.2017.06.004

[25] Akagi, T., Kaneko, T., Kida, T. and Akashi, M. (2005) Preaparation and Characterization of Biodegradable Nanoparticles Based on Poly(G-Glutamic Acid) with 1-Phenylalanine as a Protein Carrier. Journal of Controlled Release, 108, 226-236. https://doi.org/10.1016/j.jconrel.2005.08.003

[26] Kamal, S., Jayaganthan, R. and Prakash, S. (2009) Evaluation of Cyclic Hot Corrosion Behaviour of Detonation Gun Sprayed $\mathrm{Cr}_{3} \mathrm{C}_{2}-25 \% \mathrm{NiCr}$ coatings on Nickel- and Iron-Based Superalloys. Surface and Coatings Technology, 203, 1004-1013. https://doi.org/10.1016/j.surfcoat.2008.09.031

[27] Krishnamoorthy, P.R., Seetharamu, S. and Sampathkumaran, P. (1993) Influence of the Mass Flux and Impact Angle of the Abrasive on the Erosion Resistance of Materials Used in Pulverized Fuel Bends and Other Components in Thermal Power Stations. Wear, 165, 151-157. https://doi.org/10.1016/0043-1648(93)90330-O

[28] Chan, C.K., Peng, H., Liu, G., Mcilwrath, K., Zhang, X.F., Huggins, R.A., et al. (2007) High-Performance Lithium Battery Anodes Using Silicon Nanowires. Nature Nanotechnology, 3, 31-35. https://doi.org/10.1038/nnano.2007.411

[29] Bruce, P.G., Freunberger, S.A., Hardwick, L.J. and Tarascon, J.-M. (2012) Li-O 2 and Li-S Batteries with High Energy Storage. Nature Materials, 11, 19-29. https://doi.org/10.1038/nmat3191

[30] Sharma, P. (2015) Potential Application of Nanomaterials. International Journal for 
Research in Applied Science \& Engineering Technology, 3, 302-304.

[31] Khot, L.R., Sankaran, S., Maja, J.M., Ehsani, R. and Schuster, E.W. (2012) Application of Nanomaterials in Agricultural Production and Crop Protection: A Review. Crop Protection, 35, 64-70. https://doi.org/10.1016/j.cropro.2012.01.007

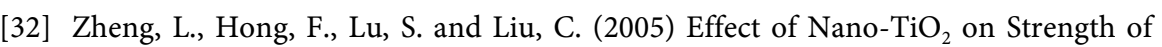
Naturally Aged Seeds and Growth of Spinach. Biological Trace Element Research, 104, 83-91. https://doi.org/10.1385/BTER:104:1:083

[33] Lima, A.C., Ceragioli, H.J., Cardoso, K.C., Peterlevitz, A.C., Zanin, H.G., Baranauskas, V. and Silva, M.J. (2010) Synthesis and Application of Carbon Nanostructures on the Germination of Tomato Seeds. In: Riberio, C., de-Assis, O.B.G., Mattoso, L.H.C. and Mascarenas, S., Eds., Symposium of International Conference on Food and Agricultural Applications of Nanotechnologies, São Pedro, SP, Brazil.

[34] Bouwmeester, H., Dekkers, S., Noordam, M.Y., Hagens, W.I., Bulder, A.S., de Heer, C., ten Voorde, S.E.C.G.S., Wijnhoven, W.P., Marvin, H.J.P. and Sips, A.J.A.A.M. (2009) Review of Health Safety Aspects of Nanotechnologies in Food Production. Regulatory Toxicology and Pharmacology, 53, 52-62.

https://doi.org/10.1016/j.yrtph.2008.10.008

[35] Bergeson, L.L. (2010) Nanosilver Pesticide Products: What Does the Future Hold? Environmental Quality Management, 19, 73-82. https://doi.org/10.1002/tqem.20263

[36] Boonham, N., Glover, R., Tomlinson, J. and Mumford, R. (2008) Exploiting Generic Platform Technologies for the Detection and Identification of Plant Pathogens. $\mathrm{Eu}$ ropean Journal of Plant Pathology, 121, 355-363. https://doi.org/10.1007/s10658-008-9284-3

[37] Singh, K., Panghal, M., Kadyan, S. and Yadav, J.P. (2014) Evaluation of Antimicrobial Activity of Synthesized Silver Nanoparticles Using Phyllanthus amarus and Tinospora cordifolia Medicinal Plants. Journal of Nanomedicine \& Nanotechnology, 5, 250-254. https://doi.org/10.4172/2157-7439.1000250

[38] Connolly, J.M., Raghavan, V., Owens, P., Wheatley, A., Keogh, I., et al. (2014) Nanogold-Based Photosensitizers Probes for Dual-Model Bioimaging and Therapy of Cancer. Journal of Nanomedicine \& Nanotechnology, 5, 249-253. https://doi.org/10.4172/2157-7439.1000249

[39] Hsiao, I., Gramatke, A.M., Joksimovic, R., Sokolowski, M., Gradzielski, M., et al. (2014) Size and Cell Type Dependent Uptake of Silica Nanoparticles. Journal of Nanomedicine \& Nanotechnology, 5, 248-250.

[40] Duncan, T.V. (2011) Applications of Nanotechnology in Food Packaging and Food Safety: Barrier Materials, Antimicrobials and Sensors. Journal of Colloid and Interface Science, 363, 1-24. https://doi.org/10.1016/j.jcis.2011.07.017

[41] Novoselov, K.S., Geim, A.K., Morozov, S.V., Jiang, D., Zhang, Y., Dubonos, S.V., Grigorieva I.V. and Firsov, A.A. (2004) Electric Field Effect in Atomically Thin Carbon Films. Science, 306, 666-669. https://doi.org/10.1126/science.1102896

[42] Malik, M.A., Revaprasadu, N. and Ramasamy, K. (2013) Nanomaterials for Solar Energy. Nanoscience, 1, 29-59.

[43] Wlodarczyk, R., Zasada, D., Morel, S. and Kacprzak, A. (2016) A Comparison of Nickel Coated and Uncoated Sintered Stainless Steel Used as Bipolar Plates in Low-Temperature Fuel Cells. International Journal of Hydrogen Energy, 39, 1-8. https://doi.org/10.1016/j.ijhydene.2016.07.231

[44] Jun, L., Chen, Z., Ma, Z., Pan, F., Curtiss, L.A. and Amine, K. (2016) The Role of Nanotechnology in the Development of Battery Materials for Electric Vehicles. Nature Nanotechnology, 11, 1031-1038. https://doi.org/10.1038/nnano.2016.207 
[45] Runowski, M. (2014) Nanotechnologia-nanomateriały, nanocząstki i wielofunkcyjne nanostruktury typu rdzeń/powłoka. Chemik, 68, 766-775.

[46] Raab, C., Simko, M., Fideler, U., Nentwich, M. and Gazso, A. (2011) Production of Nanoparticles and Nanomaterials. Nanotrust Dossier, 1-4.

[47] Liu, Z., Zhou, X. and Qian, Y. (2010) Synthetic Methodologies for Carbon Nanomaterials. Advanced Materials, 22, 1963-1966. https://doi.org/10.1002/adma.200903813

[48] Kumar, M., Pathak, A., Singh, M. and Singla, M.I. (2010) Fabrication of Langmuir-Blodgett Film from Polyvinylpyrrolidone Stabilized NiCo Alloy Nanoparticles. Thin Solid Films, 519, 1445-1451. https://doi.org/10.1016/j.tsf.2010.09.028

[49] Paul, S., Pearson, C., Molloy, A., Cousins, M.A., Green, M., Kolliopoulou, S., Dimitrakis, P., Normand, P., Tsoukalas, D. and Petty, M.C. (2003) Langmuir-Blodgett Film Deposition of Metallic Nanoparticles and Their Application to Electronic Memory Structures. Nanoletters, 3, 533-536. https://doi.org/10.1021/nl034008t

[50] Ganachari, S.V., Banapurmath, N.R., Salimath B., Yaradoddi J.S., Shettar, A.S., et al. (2017) Synthesis Techniques for Preparation of Nanomaterials. In: Martínez, L., Kharissova, O. and Kharisov, B., Eds., Handbook of Ecomaterials, Springer, Cham. https://doi.org/10.1007/978-3-319-48281-1_149-1

[51] Wlodarczyk, R. (2016) Technologie wodorowe-wodorowe ogniwa paliwowe. Wiedza i technologia motorem gospodarki, Częstochowa.

[52] Larminie, J. and Dicks, A. (2003) Fuel Cell Systems Explained. Wiley \& Sons, Ltd., New York. https://doi.org/10.1002/9781118878330

[53] Gazdzicki, P., Mitzel, J., Dreizler, A,M., Schulze, M. and Friedrich, K.A. (2017) Impact of Platinum Loading on Performance and Degradation of Polymer Electrolyte Fuel Cell Electrodes Studied in a Rainbow Stack. Fuel Cells, 18, 270-278. https://doi.org/10.1002/fuce.201700099

[54] Zhang, S., Yuan, X.-Z., Hin, J.N.C., Wang, H., Friedrich, K.A. and Schulze, M. (2009) A Review of Platinum-Based Catalyst Layer Degradation in Proton Exchange Membrane Fuel Cells. Journal of Power Sources, 194, 588-600. https://doi.org/10.1016/j.jpowsour.2009.06.073

[55] Majlan, E.H., Rohendi, D., Daud, W.R.W., Husaini, T. and Haque, M.A. (2018) Electrode for Proton Exchange Membrane Fuel Cells: A Review. Renewable and Sustainable Energy Reviews, 89, 117-134. https://doi.org/10.1016/j.rser.2018.03.007

[56] Tasic, G.S., Miljanic, S.S., Kaninski, M.P.M., Saponjic, D.P. and Nikolic, V.M. (2009) Non-Noble Metal Catalyst for a Future Pt Free PEMFC. Electrochemistry Communications, 11, 2097-2100. https://doi.org/10.1016/j.elecom.2009.09.003

[57] Grigoriev, S.A., Millet, P., Dzhus, K.A., Middleton, H., Saetre, T.O. and Fateev, V.N. (2010) Design and Characterization of Bi-Functional Electrocatalytic Layers for Application in PEM Unitized Regenerative Fuel Cells. International Journal of $\mathrm{Hy}$ drogen Energy, 35, 5070-5076. https://doi.org/10.1016/j.ijhydene.2009.08.081

[58] Haan, J.L. and Masel, R.I. (2009) The Influence of Solution pH on Rates of an Electrocatalytic Reaction: Formic Acid Electrooxidation on Platinum and Palladium. Electrochimica Acta, 54, 4073-4078. https://doi.org/10.1016/j.electacta.2009.02.045

[59] Kim, D.S., Zeid, E.F.A. and Kim, Y.-T. (2010) Additive Treatment Effect of $\mathrm{TiO}_{2}$ as Supports for Pt-Based Electrocatalysts on Oxygen Reduction Reaction Activity. Electrochimica Acta, 55, 3628-3633. https://doi.org/10.1016/j.electacta.2010.01.055

[60] Wlodarczyk, R., Chojak, M., Miecznikowski, K., Kolary, A., Kulesza, P.J. and Marassi, R. (2006) Electroreduction of Oxygen at Polyoxometallate-Modified Glassy 
Cabon-Supported Pt Nanoparticles. Journal of Power Sources, 159, 802-809. https://doi.org/10.1016/j.jpowsour.2005.11.061

[61] Chojak, M., Kolary-Zurowska, A., Wlodarczyk, R., Miecznikowski, K., Karnicka, K., Pałys, B., Marassi, R. and Kulesza, P.J. (2007) Modification of Pt Nanoparticles with Polyoxometallate Monolayers: Competition between Activation and Blocking of Reactive Sites for the Electrocatalytic Oxygen Reduction. Electrochimica Acta, 52, 5574-5581. https://doi.org/10.1016/j.electacta.2007.01.063

[62] Wlodarczyk, R., Kolary-Zurowska, A., Marassi, R., Chojak, M., Kulesza, P.J. and Marassi, R. (2007) Enhancement of Oxygen Reduction by Incorporation of Heteropolytungstate into the Electrocatalytic Ink of Carbon Supported Platinum Nanoparticles. Electrochimica Acta, 52, 3958-3964.

https://doi.org/10.1016/j.electacta.2006.11.011

[63] Wlodarczyk, R., Dudek A., Kobylecki, R., Bis, Z. (2009) Characteristic of Fuel Cells in Aspect of Theirs Productions and Application. Monografie Komitetu Inżynierii Środowiska PAN, Lublin, 273-280.

[64] Zhang, J. (2011) Recent Advances in Cathode Electrocatalysts for PEM Fuel Cells. Frontiers in Energy, 5, 137-148. https://doi.org/10.1007/s11708-011-0153-y

[65] Markovic, N.M., Gasteiger, H.A., Grgur, B.N. and Ross P.N. (1999) Oxygen Reduction Reaction on $\mathrm{Pt}(111)$ : Effects of Bromide. Journal of Electroanalytical Chemistry, 467, 157-163. https://doi.org/10.1016/S0022-0728(99)00020-0

[66] Antolini, E. (2003) Review Formation, Microstructural Characteristics and Stability of Carbon Supported Platinum Catalysts for Low Temperature Fuel Cells. Journal of Materials Science, 38, 2995-3005.

[67] Taniguchi, A., Akita, T., Yasuda, K. and Miyazaki, Y. (2004) Analysis of Electrocatalyst Degradation in PEMFC Caused by Cell Reversal during Fuel Starvation. Journal of Power Sources, 130, 42-49. https://doi.org/10.1016/j.jpowsour.2003.12.035

[68] Rajalakshmi, N. and Dhathathreyan, K.S. (2008) Nanostructured Platinum Catalyst Layer Prepared by Pulsed Electrodeposition for use in PEM Fuel Cells. Int. J. Hydrogen Energy, 33, 5672-5677. https://doi.org/10.1016/j.ijhydene.2008.05.100

[69] Santos, A.L., Profeti, D. and Olivi, P. (2005) Electrooxidation of Methanol on Pt Microparticles Dispersed on $\mathrm{SnO}_{2}$ Thin Films. Electrochimica Acta, 50, 2615-2621. https://doi.org/10.1016/j.electacta.2004.11.006

[70] Iwase, M. and Kawatsu, S. (1995) Optimized Co Tolerant Electrocatalyst for Polimer Electrolyte Fuel Cells. Proceedings of the First International Symposium on Proton Conducting Membrane Fuel Cell, 1, 12-18. https://doi.org/10.1149/199523.0012PV

[71] de Bruijn, F.A., Papageorgopoulos, D.C., Sitters, E.F. and Janssen, G.J.M. (2002) The Influence of Carbon Dioxide on PEM Fuel Cell Anodes. Journal of Power Sources, 110, 117-124. https://doi.org/10.1016/S0378-7753(02)00227-6

[72] Bonilla, S.H., Zinola, C.F., Rodríguez, J., Díaz, V., Ohanian, M., Martínez, S. and Giannetti, B.F. (2005) Catalityc Effects of Ruthenium and Osmium Spontaneous Deposition on Platinum Surfaces toward Methanol Oxidation. Journal of Colloid and Interface Science, 288, 377-386. https://doi.org/10.1016/j.jcis.2005.03.039

[73] Jiang, J. and Kucernak, A. (2002) Electrooxidation of Small Organic Molecules on Mesoporous Precious Metal Catalysts I: CO and Methanol on Platinum. Journal of Electroanalytical Chemistry, 533, 153-165. https://doi.org/10.1016/S0022-0728(02)01083-5

[74] Gan, L., Heggen, M., Rudi, S. and Strasser, P. (2012) Core-Shell Compositional Fine 
Structures of Dealloyed PtxNi1-x Nanoparticles and Their Impact on Oxygen Reduction Catalysis. Nano Letters, 12, 5423-5430. https://doi.org/10.1021/nl302995z

[75] Guo, S., et al. (2013) FePt and CoPt Nanowires as Efficient Catalysts for the Oxygen Reduction Reaction. Angewandte Chemie International Edition, 52, 465-468. https://doi.org/10.1002/anie.201209871

[76] Choi, S.I., et al. (2013) Synthesis and Characterization of $9 \mathrm{~nm}$ Pt-Ni Octahedra with a Record High Activity of $3.3 \mathrm{~A} / \mathrm{mg}(\mathrm{Pt})$ for the Oxygen Reduction Reaction. Nano Letters, 13, 3420-3425. https://doi.org/10.1021/nl401881z

[77] Flyagina, I., Hughes, K.J., Pourkashanian, M. and Ingham, D.B. (2014) DFT Study of the Oxygen Reduction Reaction on Iron, Cobalt and Manganese Macrocycle Active Sites. International Journal of Hydrogen Energy, 39, 21538-21546. https://doi.org/10.1016/j.ijhydene.2014.09.075

[78] Wang, E.W., Guo, S.J. and Dong, S.J. (2010) Three-Dimensional Pt-on-Pd Bimetallic Nanodendrites Supported on Graphene Nanosheet: Facile Synthesis and Used as an Advanced Nanoelectrocatalyst for Methanol Oxidation. ACS Nano, 4, 547-555. https://doi.org/10.1021/nn9014483

[79] Gasteiger, H. A. and Markovic, N.M. (2009) Just a Dream-Or Future Reality? Science, 324, 48-49. https://doi.org/10.1126/science.1172083

[80] Thompsett, D. (2003) Handbook of Fuel Cells. John Wiley \& Sons, Ltd, Chichester, 467.

[81] Finashina, E.D., Tkachenko, O.P., Startseva, A.Y., Krasovsky, V.G., Kustov, L.M. and Beletskaya, I.P. (2015) Three-Component $\mathrm{Au}-\mathrm{Chitosan}-\mathrm{SiO}_{2}$ Systems as Heterogeneous Catalysts for Intramolecular Cyclization of 2-(2-Phenylethynyl)Aniline. Russian Chemical Bulletin, 64, 2816-2820. https://doi.org/10.1007/s11172-015-1232-8

[82] Chen, A.C. and Holt-Hindle, P. (2010) Platinum-Based Nanostructured Materials: Synthesis, Properties, and Applications. Chemical Reviews, 110, 3767-3804. https://doi.org/10.1021/cr9003902

[83] Stamenkovic, V.R., Fowler, B., Mun, B.S., Wang, G.F., Ross, P.N., Lucas, C.A. and Markovic, N.M. (2007) Improved Oxygen Reduction Activity on Pt3Ni(111) via Increased Surface Site Availability. Science, 315, 493-497. https://doi.org/10.1126/science.1135941

[84] Wang, E.K. and Guo, S.J. (2011) Noble Metal Nanomaterials: Controllable Synthesis and Application in Fuel Cells and Analytical Sensors. Nano Today, 6, 240-264. https://doi.org/10.1016/j.nantod.2011.04.007

[85] Mukerjee, S., Srinivasan, S., Soriaga, M.P. and Mcbreen, J. (1995) Role of Structural and Electronic-Properties of Pt and Pt Alloys on Electrocatalysis of Oxygen Reduction: An in-Situ XANES and EXAFS Investigation. Journal of the Electrochemical Society, 142, 1409-1422. https://doi.org/10.1149/1.2048590

[86] Zhang, J., Sasaki, K., Sutter, E. and Adzic, R.R. (2007) Stabilization of Platinum Oxygen-Reduction Electrocatalysts Using Gold Clusters. Science, 315, 220-222. https://doi.org/10.1126/science.1134569

[87] Valiyaveettil, S., Asharani, P.V., Yi, L.W. and Gong, Z.Y. (2011) Comparison of the Toxicity of Silver, Gold and Platinum Nanoparticles in Developing Zebrafish Embryos. Nanotoxicology, 5, 43-54. https://doi.org/10.3109/17435390.2010.489207

[88] Shao, Y.Y., Yin, G.P. and Gao, Y.Z. (2007) Understanding and Approaches for the Durability Issues of Pt-Based Catalysts for PEM Fuel Cell. Journal of Power Sources, 171, 558-566. https://doi.org/10.1016/j.jpowsour.2007.07.004

[89] Gyenge, E., Atwan, M. and Northwood, D. (2006) Electrocatalysis Electrocatalysis 
of Borohydride Oxidation on Colloidal Pt and Pt-Alloys (Pt-Ir, Pt-Ni, and Pt-Au) and Application for Direct Borohydride Fuel Cell Anodes. Journal of the Electrochemical Society, 153, A150-A158. https://doi.org/10.1149/1.2131831

[90] Mu, Y., Liang, H., Hu, J., Jiang, L. and Wan, L. (2005) Controllable Pt Nanoparticle Deposition on Carbon Nanotubes as an Anode Catalyst for Direct Methanol Fuel Cells. The Journal of Physical Chemistry B, 109, 22212-22216. https://doi.org/10.1021/jp0555448

[91] Sun, S.H., Jaouen, F., Dodelet, J.P. (2008) Controlled Growth of Pt Nanowires on Carbon Nanospheres and Their Enhanced Performance as Electrocatalysts in PEM Fuel Cells. Advanced Materials, 20, 3900-3904. https://doi.org/10.1002/adma.200800491

[92] Wlodarczyk, R. and Kwarciak-Kozlowska, A. (2019) Analysis of the Sorption Possibilities of Silver Nanoparticles of Anthropogenic Origin Using Biochar. Przemysł Chemiczny, 91, 1000-1003.

[93] Kelsall, R.W., Hamley, I.W. and Geoghegan, M. (2009) Nanotechnologies, PWN, Warszawa 2009. 